\title{
HORACE ON AUGUSTUS: FACT OR FICTION?
}

\author{
S Thom (University of Stellenbosch)
}

Quot homines tot sententiae seems a good summary of the variety of critical readings of lyric poetry in general and of Horace's position on Augustus in particular. This raises the interesting question of the position of factual information in poetry: does lyric as genre imply a choice for fiction as opposed to fact or can some references to contemporary personalities or incidents be taken as realistic? In this case specifically: can what Horace says about Augustus be taken as a realistic assessment of the emperor? To complicate matters, Augustus was a powerful personage who wanted and often managed to put his own stamp on things ${ }^{1}$ in himself an embodiment of the opposition between fact and fiction.

Given this undoubtedly heady mix, the paper will try to make some sense of its topic even if it aims to do so in a very limited and practical way. ${ }^{2}$ It will not analyse Horace's letter to Augustus (Epistle 2.1) in detail since this letter focuses on the problem of how difficult it is to write, inter alia, about Augustus in poetry, rather than reflecting Augustus through poetry. ${ }^{3}$ Nor will it concentrate on the Carmen saeculare celebrating, as it does, achievements under Augustus and the establishment of a golden age rather than portraying Augustus himself (Baker 1996:434-446). The paper's very straightforward aim is to assess Horace's use of references to Augustus. It will try to see if the poet is at all consistent in his use of such references and, if he is, what can be deduced from such consistency. ${ }^{4}$

There seems to be a variety of critical readings of Horace's position on Augustus. For the purpose of this paper I shall summarise these readings very briefly and, because of that, unfortunately without much nuance. There are those scholars who maintain that Horace, especially in his political work, supports Augustus and the principate unequivocally. ${ }^{5}$ There

1. The Res Gestae is probably one of the best examples of self-advertisement in the ancient world.

2. See Bowersock (1994), who investigates the complexities involved in "historical" as opposed to "fictional" truths.

3. See Barchiesi (2001:especially 79-103).

4. This might include a stand for or against Augustus or any of the positions in between. The point is not in the first place to arrive at a new perspective on Augustus, but to come to a better understanding of Horace's understanding of Augustus. Given the sheer volume of work concerned, it seemed expedient to try an analysis within very specific parameters which could be checked against the larger volume, but which would not have to take that volume into consideration at the outset.

5. See Harrison (1995:1-16) for a general summary of work on Horace in the twentieth century. Pöschl (1991) is an example of a critic for whom the "otium civitatis" necessary for a poet is only possible because of Augustus's Pax Romana. White (1993), carefully analysing historical evidence, concludes that poets supporting Augustus did so exactly because of the changes (especially social) he brought about. Recently a number of critics such as Santirocco (1995) and Lyne (1995), while focusing on the text, ended up accepting both the independence of the poet and his lack of support for the regime, while Putnam (1986) sees in the aesthetic qualities of Horace's work an imperative for poetic independence. Other recent work on Horace has shown how crucial a specific critical perspective can become: critics have variously read Horace as obligated by friendship (Fraenkel 1957), deferentially aware of authority (Oliensis 1998), “manipulating” poetic rhetoric (Davis 1991) or reflecting an implicit gender bias (Ancona 1994). It is of course also possible to deconstruct the text by focusing on for instance Horace's use of specific figurative language (Lowrie 1997). However, more than 30 years ago, Doblhofer has already pointed out the basic schism reflected in Horace's world: “. . . im Gesamtwerk des Horaz [haben] zwei kontrastierende Welten ihren Niederschlag gefunden, die politische und die private, Bürgerpflicht und Otium, Stoa und Epikureismus, Stadtpalast des Maecenas und Sabinum, Welt und Ich” (1966:1927). His advice to critics 
are scholars who differ radically from this position. ${ }^{6}$ The middle position seems to be reflected by those who believe that Horace gradually moved from direct opposition to Augustus to firm support of him. ${ }^{7}$ This paper will reflect Horace's careful ambivalence, even in those Odes where critics seem to find most support for Augustus. ${ }^{8}$

One of the most telling insights into Horace's position on the emperor Augustus is an analysis of the use of the title Augustus. Horace does not refer to the Emperor by this name until well into his second book of Odes and then only once in Odes 2.9.19 and twice in the Roman odes, Odes 3.3.11 and 3.5.3. ${ }^{9}$ Interestingly enough the first ode to use the title Augustus (Odes 2.9) focuses on change and things not always (non semper 2.9.1) staying the same, ${ }^{10}$ making its point about loss and gain in a negative way. It starts out emphasizing that even bad weather cannot go on forever. Because things change Valgius should, instead of forever lamenting the loss of his Mystes, rather rejoice because of Caesar Augustus's newest trophies (land acquisitions) in the east (potius nova cantemus Augusti tropaea Caesaris, 2.9.18-20). It does not need an uncommonly perceptive mind to realize that the connection being made between the loss of a beloved and the gain of yet another addition to the conquered nations (gentibus victis, 2.9.21-22) of an empire, reflects on both Valgius' loss and Augustus' gain. It seems to me that this connection underlines the fundamental difference between the subject matter normally associated with lyric as opposed to that reflected in historiography or, to put it more generally, the difference between a preoccupation with the personal or private vs. the public or collective. ${ }^{11}$ The very discrepancy between Valgius' loss and Augustus' gain implies fundamental distaste and even criticism of the gain, which after all represents a fundamental loss of freedom to the conquered (gentibus victis) as reflected in the last stanza (2.9.21-24) by the encroaching boundaries that shrink the once open plains. There may be superficial support for the fact that the emperor Augustus is the victor, but poetically the title Augustus packs out in a much more ambivalent way.

In Odes 3.3.11 the emperor Augustus is depicted drinking nectar and reclining with others, who by their own efforts, have ensured their immortality. Again, there seems to be a definite line drawn between the private, lyric world (stanzas one and two) and the alternative public world where Augustus, according to the ironic perspective of the poet, managed to ensure his own immortality (stanza three to seventeen) by virtue of the effort of others. The alternative public world and its achievements are portrayed in great detail and very persuasively, just to be completely undermined in the last stanza where Horace addresses his Muse directly as

still holds true: "Diesen Nebel behutsam zu zertreuen, ohne dabei etwa der Poesie Abbruch zu tun, gehört zu den unmittelbar anstehenden Aufgabe der Horazforschung” (1966:1927).

6. See Santirocco (1995) and Lyne (1995) quoted above.

7. See Putnam (1986) quoted above. See Witke (1983) for the opposite position, i.e. moving away from initial support for Augustus.

8. It might also be expedient to make my own bias clear from the start. I read Horace as being consistently ambivalent about Augustus even in Odes 4 by which time most critics take Horace's support for Augustus as explicit. See Putnam (1986) for bibliography on Horace's support for Augustus and Witke (1983) for evidence of Horace's initial full support of Augustus but withdrawal of that support after Odes 1-3.

9. Horace could obviously not refer to Augustus by his title before Octavian claimed the title for himself.

10. The time factor is underlined very explicitly by the repeated use of the word semper (2.9.1, 9 and 17).

11. Miller (1994:144) points out that "Horace allows the private world of lyric to engage the public and political realms, without denying the relative autonomy of each." This tension in Horace between the private and the public voice or that between public engagement and private withdrawal (Johnson 1982: 142) has long been noticed, but the interrelatedness of the voices, or, of engagement and withdrawal, is not always sufficiently taken into account. 
follows: "what are you aiming for, o Muse? Stop wilfully undermining great things with little efforts" (quo, Musa, tendis? desine pervicax ... magna modis tenuare parvis, 3.3.70-72). This light-hearted deconstruction of an historical reality reflected in the public sphere, implies that Augustus' own elevation to immortality right at the beginning of the more public section of the poem (stanza three) was also supposedly "inadequately" explained. The implication is much more ambivalent though, since it manages, in retrospect, to undermine Augustus' very elevation to the gods, and not only the portrayal thereof in poetry.

Odes 3.5 uses the same technique of supposedly describing something positive: Augustus becomes a god, because of (again other people's) military conquests of the Britons and the Parthians (stanza one). The remainder of the ode gives a portrayal of what such conquests cost the Romans in terms of how Roman citizens behave in the present. It is in direct contrast with the example of the real honour of a man like Regulus. The direct connection between past honour and present depravity raises the tricky question of how to justify Augustus being godly (divus, the reward for his conquests) if his divinity generates present dishonour (the consequences of these conquests). Furthermore, if Rome in the past has produced men of true honour, hinting at a general lack of honour in men of the present, achievements under Augustus as well as his supposed godliness become suspect. On balance in Odes books 1-3 the references to Augustus' title may be factual and incidental, but they have a quite deadly poetic sting in the tail, which is emotional and not incidental at all.

It seems then that by 23 BC Horace is, at the least, quite ambivalent about Augustus whenever he uses this title, even if he is mostly ambivalent or negative only by implication. We next find a reference to Augustus by that name in the letter to Florus (Epistle 2.2.28). The reference seems again to be incidental occurring in a description of Horace's disastrous participation in Brutus' opposition to Augustus at Philippi and his own subsequent focus on poetry as a means of earning a living (Epistle 2.2.49-52). In historical terms, however, this battle was a turning point, after which the empire became not only a distinct possibility, but also a reality. Other references to the title Augustus in the Epistles are seemingly equally casual and incidental. Tiberius may be indicated only as Augustus' stepson (Augusti privignu, Epistle 1.3.2) but the exploits of Augustus (gestas Augusti, Epistle 1.3.7) deserving praise are really the deeds of Tiberius. In Epistle 1.13 Augustus is the recipient of a copy of Horace's poems, but only under a list of such special circumstances that the gift seems to cast doubt (albeit playfully) on the suitability of the recipient rather than the other way around. And finally, Augustus is mentioned in Epistle 1.16 where praise for him could be read into a line, or not, depending on the listener's personal willingness to express such praise (Augusti laudes agnoscere possis, Epistle 1.16.29). On balance, mention of Augustus in the Epistles cannot be regarded only as casual or incidental references to the title. More often than not, such references are ambivalent or even negative.

In what is generally taken as one of his last works, Odes 4, Horace uses the title Augustus in three of the 15 poems. In Odes 4.2, where the Greek poet Pindar is praised as celebrating the blood or offspring of the gods (deorum sanguinem 4.2.13-14), Augustus is described as the greatest gift to mankind both from the Fates and the gods (quo nihil maius meliusve terris fata donavere bonique divi, 4.2.37-38). This is extravagant praise indeed and seems to represent at least some kind of fundamental volte-face in Horace's position on Augustus, especially if compared to the implied negativity or the ambivalence of previous references to him. If one takes into account, however, that in the previous ode (4.1) the poet questions his own re-engaging in poetic activity in a very fundamental way (Harrison 1995:108-127), an ironic light is cast on the extravagant praise of the emperor. Furthermore, the poem's 
ambivalence even on Horace's ability as poet is striking, if his voice fails him at the crucial moment (inter verba cadit lingua silentio? Odes 4.1.36). ${ }^{12}$ These factors are sufficient to cast doubts on, or at least question thoroughly, all Horace is saying about Augustus in the very next poem. $^{13}$

Horace's next mention of Augustus is in Odes 4.4 at the end of a 28 line introductory sentence. It seems though that the moment when Augustus is described as the gods' gift to mankind the need for his immediate replacement is pushed to the fore. In this second reference to Augustus in Odes 4, it is striking that Augustus is mentioned only in terms of his relationship to possible successors and especially in terms of his fatherly devotion to the young Neros (Augusti paternus in pueros animus Nerones, 4.4.27-28). In addition, even more strikingly, the poem ends with a panegyric on Tiberius' achievements, pointing out that the hand of Tiberius (not that of Augustus) will accomplish all (nil Claudiae non perficient manus, 4.4.73). Furthermore, it is Jupiter, the father of the gods, who with benign power guarantees Tiberius' position (quas et benigno numine Iuppiter defendit, 4.4.74) rather than the less specific Fates or impersonal gods that supported Augustus and designated him as a great gift to mankind. It seems then as if Augustus as the "greatest gift to mankind" is a fleeting gift and a gift only in passing. This seems to imply some support for the system, but not for the man.

In the last reference to Augustus in Odes $4^{14}$ the emperor is addressed directly (Odes 4.14). Again there is extravagant praise for Augustus implied in the need felt by the citizens and senators (cura patrum, 4.14.1) of Rome to immortalise his exploits ([Augusti] virtutes ... aeternet, 4.14.3-5). Augustus is called the greatest of princes (maxime principum, 4.14.6), ${ }^{15}$ but this reference to his greatness is then shown as due, not to his own actions, but to the achievements of Drusus and Tiberius. Their deeds are specifically mentioned and are described in great detail. Augustus might have supplied the infrastructure, the planning and the emotional support (te copias, te consilium et tuos praebente divos, 4.14.33-34), but the actual victories were won only by proxy. It seems as if Horace is using a narratological technique also later used to good effect by Tacitus, where the longer and more detailed passage has greater emotional impact than the shorter and more general passing comment.

12. Horace's recusatio transposes the burden of praise for Augustus onto Iullus Antonius who is exhorted to write a panegrical epic on Augustus' achievements. Horace limits himself to the most mundane of expressions: "o sol pulcher, o laudande" (o beautiful sun, o sun to be praised). See Harrison (1995:123) for sustained and persuasive argument on the above. I agree with Harrison that Horace is adopting the pose of not being capable of praising Augustus since he is merely a simple member of the crowd. I agree that Horace adopts this pose with a literary aim in mind, but I maintain he does so for a far more sinister purpose than Harrison proposes. To my mind Horace distances himself from praise of Augustus by pretending to become part of the profanum vulgus which he deemed as lacking in proper understanding in all other circumstances. Cf. Syndikus (1972-3:345) who underlines the growing alienation of the ordinary citizen towards the state. The tribute offered, therefore, is not praise of Augustus, but rather a celebration of the poet's bee-like (industrious, but easily overlooked) creative ingenuity.

13. According to Seager (in Rudd 1993:36) "what is said of Augustus is curiously ambiguous" again underlining lyric ability to reflect meaning on different levels.

14. Odes 4.5 ("the most Fascist of [Horace's] odes" according to Fowler $(1995: 258)$ ) carefully avoids addressing Augustus by anything more exhalted than "dux": longas o utinam, dux bone, ferias/praestes Hesperiae! (4.5 37-38: may you grant long holidays to Italy, o good leader). See Du Quesnay (in Harrison 1995:127-187) for a detailed analysis of Odes 4.5.

15. This echoes Odes 1.2.50 where the initial power of father Jupiter (Pater, 1.2.2) is finally contrasted to Augustus's power as pater atque princeps (1.2.50). 
The reader is left with the clear impression that the situation reflected here has two distinct sides. ${ }^{16}$ Since he does not give any further indications to the contrary, it seems as if Horace accepts the current political system, where Augustus is planning to hand over the government to his direct heir or heirs. Horace, however, even if he is ready to accept the system, is not ready to grant Augustus himself such acceptance. He might praise Augustus as a gift from the gods, but only in passing. The next emperor is already waiting in the wings.

Ironically enough, the final book of odes ends with a reference to the combined Trojan and godly ancestry of the new dynasty founded by Augustus (Anchisen et almae progeniem Veneris 4.15.32). This probably represents the most direct marginalising possible of the current ruler, since he is reduced to but a single entry on a list dating from what was then seen as the dawn of time. ${ }^{17}$

To sum up, Horace uses the title Augustus in a consistently ambivalent way. ${ }^{18}$ Where he does associate positive aspects of the principate with the title, there is ambiguity or innuendo of the type that we come to expect of a politician like Tacitus, rather than a poet loyal to a sportive muse (non hoc iocosae conveniet lyrae, 3.3.69). According to this reading of Horace on Augustus, Horace did not gradually change into a supporter of Augustus, even if he did gradually come to accept the new political system. ${ }^{19}$

I have tried to illustrate Horace's rather ambivalent use of the title Augustus as the most obvious instrument in his evaluation of the title-bearer's res gestae. In conclusion then it appears that Horace was rarely as supportive of Augustus and his achievements as is sometimes or even often believed. His support was frequently given in a quite ambivalent way, being much more nuanced than one would expect from a poet supposedly dealing in fiction. He gave an extremely realistic assessment of the emperor Augustus and certainly did not suspend criticism of him in any way.

On the other hand, an awareness of the real collective chaos, which Augustus kept at bay, tempered the irritation Horace must have felt as an individual whose creative intelligence balked at the obvious strictures which surrounded him. If poetry was a voyage of discovery as foreseen in Odes 1.3, it must have been extremely irksome to realise that the state and society, encouraged by the state, required the poet to hug the coast so closely. Nevertheless, at least the state did not impede the passage. Horace's great advantage was that his work at least, was not curtailed since he could always claim fiction rather than fact as justification for what he wrote.

In the final analysis, Horace was not interested in the limits imposed or opportunities granted by a specific political system. It is quite telling that the poet, Horace so often had

16. Miller (1994:142) refers to the period which produced writers like Vergil and Horace as the "twilight time", underlining its transitional character which combined the need for the "pretense of the Augustan restoration" (1994:143) with the ultimately destructive effect it had on lyric poetry.

17. Ironically Horace himself could not have known how problematical the eventual succession would be.

18. It is obvious that even an analysis of all the references to Horace's use of the title "Augustus" cannot be sufficient to sustain the case for Horace's consistent ambivalence about the emperor. The important point is, however, that once such consistent ambivalence is clear even in what could be described as the use of a technical term, it is much easier to find evidence of consistent ambivalence toward Augustus by means of close analysis of whole poems.

19. Accepting the system, however, would always be easier for someone whose private voice has never been stilled, whose very muse made fun of and so undermined an all too serious perspective on life. 
recourse to what critics call "colloquial language" to ground his poetry in at least a semblance of fact, as if he wanted to establish beyond any doubt the validity of truth existing in fiction.

\section{BIBLIOGRAPHY}

Ancona, R 1994. Time and the erotic in Horace's Odes. Durham: Duke University Press.

Baker, D 1996. The golden age is proclaimed? The Carmen saeculare and the renascence of the golden race. CQ N.S. 46(2):434-466.

Barchiesi, A 2001. Speaking volumes: Narrative and intertext in Ovid and other Latin poets, esp 79 103 (edited and translated by Fox, M and Marchiesi, S). London: Duckworth.

Bowersock, G W 1994. Fiction as history: Nero to Julian. Berkeley: University of California Press.

Davis, G 1991. Polyhumnia. The rhetoric of Horatian lyric discourse. Berkeley: University of California Press.

Doblhofer, E 1966. Horaz und Augustus. ANRW II 31.3.1922 - 1986.

Du Quesnay, I M le M 1995. Horace, Odes 4.5: Pro reditu imperatoris Caesaris divi filli Augusti. In Harrison, S J (ed.), Homage to Horace: A bimillenary celebration, 128-187. Oxford: Clarendon Press.

Fowler, D P 1995. Horace and the aesthetics of politics. In Harrison, S J (ed.), Homage to Horace: A bimillenary celebration, 248-266. Oxford: Clarendon Press.

Fraenkel, E 1957. Horace. Oxford: Oxford University Press.

Harrison, S J 1995. Horace, Pindar, Iullus Antonius and Augustus: Odes 4.2. In Harrison, S J (ed.) Homage to Horace: A bimillenary celebration, 108-127. Oxford: Clarendon Press.

Harrison, S J (ed.) 1995. Homage to Horace: A bimillenary celebration. Oxford: Clarendon Press.

Johnson, W R 1982. The idea of lyric: Lyric modes in ancient and modern poetry. Berkeley: University of California Press.

Lowrie, M 1997. Horace's narrative odes. Oxford: Clarendon Press.

Lyne, R O A M 1995. Horace: Behind the public poetry. New Haven: Yale University Press.

Miller, P A 1994. Lyric texts and lyric consciousness: The birth of a genre from archaic Greece to Augustan Rome. London: Routledge.

Oliensis, E 1998. Horace and the rhetoric of authority. Cambridge: Cambridge University Press.

Pöschl, V 1970 (expanded edition 1991). Horazische Lyrik. Heidelberg: Carl Winter Universitätsverlag.

Putnam, M C J 1986. Artifices of eternity. Horace's fourth book of Odes. Ithaca: Cornell University Press.

Rudd, N (ed.) 1993. Horace 2000: A celebration. Essays for the bimillenium. London: Duckworth.

Santirocco, M 1995. Horace and Augustan ideology. Arethusa 28.2-3. 225-243.

Seager, R 1993. Horace and Augustus: Poetry and policy. In Rudd, N (ed.), Horace 2000: A celebration. Essays for the bimillenium, 23-40. London: Duckworth.

Syndikus, H P 1972 - 73. Die Lyrik des Horaz: Eine Interpretation der Oden. Band I \& II. Darmstadt: Wissenschaftliche Buchgesellschaft.

White, P. 1993. Promised verse: Poets in the society of Augustan Rome. Cambridge: Harvard University Pres.

Witke, C 1983. Horace’s Roman Odes: a critical examination. Leiden: Brill. 